\title{
Antithyroid peroxidase antibody positivity is associated with lower incidence of metastasis in breast cancer
}

\author{
YASEMIN KEMAL ${ }^{1}$, GUZIN DEMIRAG $^{1}$, KUBILAY EKIZ $^{2}$ and IDRIS YUCEL ${ }^{1}$ \\ Departments of ${ }^{1}$ Medical Oncology and ${ }^{2}$ Internal Medicine, Faculty of Medicine, \\ Ondokuz Mayis University, Samsun 55139, Turkey
}

Received October 2, 2014; Accepted January 30, 2015

DOI: $10.3892 / \operatorname{mco} .2015 .521$

\begin{abstract}
Thyroid extracts were first used to treat patients with metastatic breast cancer over a century ago. Since then, a number of studies have investigated the association between thyroid disorders and breast cancer. The presence of antibodies to thyroid peroxidase (TPOab) was recently reported to be associated with improved outcome in these patients. The aim of the present study was to evaluate the association between TPOab positivity and clinicopathological characteristics in breast cancer patients. The study included 318 newly diagnosed cases of breast cancer treated at Ondokuz Mayis University Hospital, Samsun, Turkey, between 2008 and 2012. Serum thyroid-stimulating hormone, free triiodothyronine and free thyroxine levels were measured at the time of diagnosis. Of the 318 patients, 253 were considered to be TPOab-negative (TPOab $\leq 34 \mathrm{IU} / \mathrm{ml}$ ) and 65 TPOab-positive (TPOab >34 IU/ml). No cases with distant metastases were found in the TPOab-positive group. However, 20 (7.9\%) of the 253 patients displayed distant metastases in the TPOab-negative group $(\mathrm{P}=0.01)$. Therefore, TPOab positivity was found to be associated with a lower incidence of metastasis in breast cancer patients.
\end{abstract}

\section{Introduction}

Since Beatson (1) first described the use of thyroid extracts to treat patients with metastatic breast cancer over a century ago, a number of studies have investigated the association between thyroid disorders and breast cancer (2-8). However, despite extensive population studies, the results as a whole have been inconsistent. In preclinical models, it has been found that T3 may sustain serum-free proliferation of several cell lines, including breast cancer; in addition, rodent mammary gland development and physiology have been found to be sensitive to T3 (9-11).

Correspondence to: Dr Yasemin Kemal, Department of Medical Oncology, Faculty of Medicine, Ondokuz Mayis University, Kurupelit Kampüsü, Samsun 55139, Turkey

E-mail: drturkmen@yahoo.com

Key words: thyroid peroxidase antibodies, breast cancer, metastasis, prognostic factor
Recent reports have refocused attention on the long-debated question of the possible assosiation between autoimmune thyroid disease (AITD) and breast cancer; some of the studies reported a positive association $(3,12)$, but this was not confirmed in other studies (6).

Thyroid peroxidase (TPO), is one of the main known autoantigenic targets in the thyroid gland, similar to thyroglobulin or nuclear thyroid hormone receptor, and is the antigen most closely involved in cell-mediated cytotoxicity (13-15). An elevated level of antibodies to TPO (TPOab) was reported to be the major risk factor for AITD (16). With sensitive assay techniques, $95 \%$ of the patients with hypothyroidism (Hashimoto's thyroiditis) and $85 \%$ of those with hyperthyroidism (Graves' disease) have detectable levels of TPOab (17).

It was previously reported that the AITD prevalence is higher among breast cancer patients compared to that among healthy subjects (18-20). Surprisingly, Smyth (21) demonstrated that TPOab level is inversely correlated with tumor size and axillary nodal involvement and significantly improves the outcome of breast cancer patients.

The objective of the present study was to investigate the association between TPOab and the clinicopathological characteristics of breast cancer patients.

\section{Patients and methods}

Patients. A total of 318 female newly diagnosed breast cancer patients, who were diagnosed and treated at the Ondokuz Mayis University Hospital, Samsun, Turkey, between 2008 and 2012, were included in our study. Patients with previous cancer history and those who had received therapy for thyroid disease were excluded.

Following provision of written informed consent, all the patients underwent a staging workup according to the National Comprehensive Cancer Network guidelines (https://intervalolibre.files.wordpress.com/2012/06/mama-2014.pdf).

Prior to treatment initiation, baseline serum samples were obtained to measure TPOab, serum free triiodothyronine (fT3), free thyroxine (fT4) and thyroid-stimulating hormone (TSH) levels.

The study protocol was approved by the Ethics Committee of Ondokuz Mayis University and conformed to the standards of the Helsinki Declaration. 
Table I. Characteristics of TPOab-positive and -negative patients $(\mathrm{n}=318)$.

\begin{tabular}{|c|c|c|c|}
\hline Characteristics & $\begin{array}{c}\text { TPOab } \leq 34 \mathrm{IU} / \mathrm{ml}, \text { no. }(\%) \\
(\mathrm{n}=253)\end{array}$ & $\begin{array}{c}\text { TPOab }>34 \mathrm{IU} / \mathrm{ml}, \text { no. }(\%) \\
(\mathrm{n}=65)\end{array}$ & P-value \\
\hline Age, years & $49.9 \pm 9.9$ & $50.2 \pm 8.7$ & 0.850 \\
\hline $\mathrm{fT} 3, \mathrm{pg} / \mathrm{ml}$ & $3.06 \pm 0.53$ & $3.06 \pm 0.54$ & 0.999 \\
\hline $\mathrm{fT} 4, \mathrm{ng} / \mathrm{dl}$ & $1.18 \pm 0.302$ & $1.17 \pm 0.25$ & 0.120 \\
\hline $\mathrm{TSH}, \mu \mathrm{IU} / \mathrm{ml}$ & $2.81 \pm 2.89$ & $4.48 \pm 4.9$ & 0.000 \\
\hline Nuclear grade & & & 0.549 \\
\hline I & $30(11.9)$ & $11(16.9)$ & \\
\hline II & $163(64.4)$ & $39(60.0)$ & \\
\hline III & $60(23.7)$ & $15(23.1)$ & \\
\hline Tumor size, $\mathrm{cm}$ & & & 0.800 \\
\hline $\mathrm{T} 1, \leq 2$ & $93(36.8)$ & $25(38.5)$ & \\
\hline $\mathrm{T} 2-4,>2$ & $160(63.2)$ & $40(61.5)$ & \\
\hline Lymph node metastasis & & & 0.575 \\
\hline Negative & $107(42.3)$ & $30(46.2)$ & \\
\hline Positive & $146(57.7)$ & $35(53.8)$ & \\
\hline Metastasis & & & 0.018 \\
\hline M0 & $233(92.1)$ & $65(100.0)$ & \\
\hline M1 & $20(7.9)$ & $\begin{array}{ll}0 & 0.0)\end{array}$ & \\
\hline Estrogen receptor & & & 0.128 \\
\hline Positive & $191(75.5)$ & $43(66.2)$ & \\
\hline Negative & $62(24.5)$ & $22(33.8)$ & \\
\hline Progesterone receptor & & & 0.147 \\
\hline Positive & $146(57.7)$ & $31(47.7)$ & \\
\hline Negative & $107(42.3)$ & $34(52.3)$ & \\
\hline HER2/neu & & & 0.385 \\
\hline Positive & $181(71.5)$ & $50(76.9)$ & \\
\hline Negative & $72(28.5)$ & $15(23.1)$ & \\
\hline $\begin{array}{l}\text { Local recurrence-distant } \\
\text { metastasis }\end{array}$ & & & 0.040 \\
\hline Negative & $239(88.5)$ & $64(96.9)$ & \\
\hline Positive & $14(11.5)$ & $1(3.1)$ & \\
\hline
\end{tabular}

The values are presented as mean \pm standard deviation. Bold print denotes statistically significant differences. TPOab, antibodies to thyroid peroxidase; fT3, free triiodothyronine; fT4, free thyroxine; TSH, thyroid-stimulating hormone; HER2, human epidermal growth factor receptor 2.

TPOab and hormone detection. TPOab, TSH, fT3 and fT4 levels were quantitatively measured using electrochemiluminescence immunoassay kit (Modular Analytics Evo e170; Roche Hitachi Corp., Tokyo, Japan). Normal ranges were defined according to the laboratory kits used as follows: TPOab, $0-34 \mathrm{IU} / \mathrm{ml}$, with the cut-off level set at $34 \mathrm{IU} / \mathrm{ml}$ (all cases with TPOab $\leq 34 \mathrm{IU} / \mathrm{ml}$ were considered to be negative, whereas all cases with TPOab $>34 \mathrm{IU} / \mathrm{ml}$ were considered to be positive.

Pathological evaluation. The following characteristics were investigated in all patients following breast surgery: Nuclear grade, estrogen receptor (ER) and progesterone receptor (PgR) expression, tumor size, lymph node metastasis and human epidermal growth factor receptor 2 (HER2)/neu status.
ER and PgR status and HER2 overexpression were determined by standard immunohistochemical analyses. In case of uncertainty, fluorescence in situ hybridization was performed.

Statistical analysis. Statistical analyses were performed using SPSS software for Windows, version 15 (SPSS, Inc., Chicago, IL, USA) and the results are expressed as mean \pm standard deviation. In all the tests, the $\mathrm{P}<0.05$ was considered to indicate a statistically significant difference.

The differences in categorical variables (nuclear grade, pTNM status and hormone receptor status) between the TPOab-positive and -negative groups were analyzed with the Pearson's $\chi^{2}$ test. The Mann-Whitney U test was used to evaluate the differences in TSH, fT3 and fT4 between the two groups. 


\section{Results}

Patients. Of the 318 newly diagnosed patients with breast cancer, 253 patients $(79.6 \%)$ with TPOab levels $\leq 34 \mathrm{IU} / \mathrm{ml}$ were considered as TPOab-negative and 65 (20.4\%) with TPOab $>34 \mathrm{IU} / \mathrm{ml}$ as TPOab-positive. All the metastases were detected at the time of diagnosis. No cases with distant metastases were identified among the 64 patients in the TPOab-positive group. However, $20(7.9 \%)$ of the 253 TPOab-negative patients displayed distant metastases $(\mathrm{P}=0.018)$ (Table I).

Differences in patient characteristics according to TPOAb levels. There were no significant differences between the TPOab-negative and -positive patient groups with respect to age $(\mathrm{P}=0.850)$, fT3 $(\mathrm{P}=0.999)$ and $\mathrm{fT} 4(\mathrm{P}=0.120)$, nuclear grade $(\mathrm{P}=0.549)$, tumor diameter $(\mathrm{P}=0.800)$, lymph node involvement $(\mathrm{P}=0.575)$, ER status $(\mathrm{P}=0.128), \mathrm{PgR}$ status $(\mathrm{P}=0.147)$ and HER2/neu status $(\mathrm{P}=0.385)$ (Table $\mathrm{I})$.

However, TPOab-positive patients exhibited higher TSH levels compared to TPOab-negative patients (2.81 vs. $4.48 \mu \mathrm{IU} / \mathrm{ml}$, respectively; $\mathrm{P}=0.000$ ).

Although all the patients could not be followed up over the same time period, in the TPOab-positive group only 1 patient developed distant metastasis, whereas in TPOab-negative group, distant metastasis or local 0recurrence was identified in 14 patients $(\mathrm{P}=0.040)$.

\section{Discussion}

Since the 1950s, over 30 studies have been published on the association between thyroid disorders and breast cancer; however, this association remains controversial (2-8). In 2002, Sarlis et al (22) and Simon et al (23) reported no association between breast cancer and thyroid disorders; however, Cristofallini et al (24) later demonstrated that patients with primary hypothyroidism exhibited a reduced risk for developing invasive breast cancer and that patients with invasive breast cancer and hypothyroidism may have a more indolent disease course, as they were significantly more likely to have pathologically smaller tumors. The data also suggested that lymph node involvement and hormone receptor-negative tumors (e.g., ER-negative) were also less frequent among hypothyroid patients, but this association was not statistically significant. In agreement with our study, Farahati et al (25) recently reported that the presence of TPOab is associated with a lower frequency of metastasis in breast cancer patients. However, in addition to that study, we observed that TPOab positivity may protect breast cancer patients from local recurrence or distant metastasis during the follow-up period. Similar to our findings, Smyth (21) reported a better disease outcome in 142 breast cancer patients with elevated TPOab levels compared to TPOab-negative cases. However, we were unable to identify any association between nuclear grade, ER, PgR and HER2/neu status, lymph node involvement and TPOab positivity. In March, 2014 a study conducted in Italy demonstrated that breast cancer prevalence is higher among patients with thyroid diseases; however, the subgroup analysis demonstrated that TPOab and/or antithyroglobulin antibody positivity appear to be protective against breast cancer (26).
The mechanisms through which TPOab positivity may affect breast cancer progression have not been fully elucidated. TPOab positivity has been shown to be an important factor in antibody-dependent cell cytotoxicity in the thyroid gland (27) and there may be an association between autoimmune thyroiditis and protective antitumor mechanisms. Therefore, high TPOab levels may represent an immune response against breast carcinoma and/or thyroid tissue $(15,21)$.

Thyroid hormones are involved in mammary gland development by stimulating ductal branching and alveolar budding (11). Normal mammary epithelial cells express significant amounts of thyroid hormone receptor - a member of nuclear receptor family $(28,29)$ and breast cancer cells exhibit T3-binding activity $(30,31)$. Although little was known on this issue, several investigations recently suggested that TSH and T3 may stimulate proliferation in some experimental models (24).

Spitzweg et al (32) reported that breast cancer and thyroid tissue express sodium iodide symporter genes; and Kilbane et al (33) demonstrated that breast cancer tissue iodine content was significantly lower compared to that in normal breast tissue or fibroadenoma, suggesting an iodine uptake pathology in breast cancer. Previous epidemiological studies demonstrated an inverse correlation between iodine intake and breast cancer incidence $(12,34)$.

Our study demonstrated that TPOab positivity is associated with a lower incidence of metastatic cases among breast cancer patients and a better outcome compared to negative cases.

In conclusion, primary hypothyroidism and AITD, particularly TPOab positivity, may be good prognostic factors in breast cancer patients; however, further investigations are required.

\section{Acknowledgements}

We would like to thank Dr Berkhan Topaktas for his advice on the statistical analyses.

\section{References}

1. Beatson GT: On the treatment of inoperable cases of carcinoma of the mamma: suggestions for a new method of treatment, with illustrative cases. Lancet 2: 104-107, 1986.

2. Altieri A, Tavani A, Gallus S, Bosetti C, Talamini R, Franceschi S, Levi F and La Vecchia C: Correspondence re: Simon et al., Do thyroid disorders increase the risk of breast cancer? Cancer Epidemiol Biomarkers Prev 12: 684-686, 2003.

3. Ito $\mathrm{K}$ and Maruchi N: Breast cancer in patients with Hashimoto's thyroiditis. Lancet 2: 1119-1121, 1975.

4. Rasmusson B, Feldt-Rasmussen U, Hegedüs L, Perrild H, Bech K and Høier-Madsen M: Thyroid function in patients with breast cancer. Eur J Cancer Clin Oncol 23: 553-556, 1987.

5. Shering SG, Zbar AP, Moriarty M, McDermott EW, O'Higgins NJ and Smyth PP: Thyroid disorders and breast cancer. Eur J Cancer Prev 5: 504-506, 1996.

6. Maruchi N, Annegers JF and Kurland LT: Hashimoto's thyroiditis and breast cancer. Mayo Clin Proc 51: 263-265, 1976.

7. Anker GB, Lønning PE, Aakvaag A and Lien EA: Thyroid function in postmenopausal breast cancer patients treated with tamoxifen. Scand J Clin Lab Invest 58: 103-107, 1998.

8. Kurland LT and Annegers JF: Letter: Breast cancer and Hashimoto's thyroiditis. Lancet 1: 808, 1976.

9. Nogueira CR and Brentani MM: Triiodothyronine mimics the effect of estrogen in breast cancer cell lines. J Steroid Biochem Mol Biol 59: 271-279, 1996.

10. Dinda S, Sanchez A and Moudgil V: Estrogen-like effects of thyroid hormone on the regulation of tumor suppressor proteins, p53 and retinoblastoma, in breast cancer cells. Oncogene 21: 761-768, 2002. 
11. Vonderhaar BK and Greco AE: Lobulo-alveolar development of mouse mammary glands is regulated by thyroid hormones. Endocrinology 104: 409-418, 1979.

12. Mittra I, Perrin J and Kumaoka S: Thyroid and other autoantibodies in British and Japanese women: an epidemiological study of breast cancer. Br Med J 1: 257-259, 1976.

13. Zophel K, Roggenbuck D and Schott M: Clinical review about TRAb assay's history. Autoimmun Rev 9: 695-700, 2010.

14. McLachlan SM and Rapoport B: The molecular biology of thyroid peroxidase: cloning, expression, and role as autoantigen in autoimmune thyroid disease. Endocr Rev 13: 192-206, 1992.

15. Khoury EL, Hammond L, Bottazzo GF and Doniach D: Presence of the organ-specific 'microsomal' autoantigen on the surface of human thyroid cells in culture: its involvement in complement-mediated cytotoxicity. Clin Exp Immunol 45 316-328, 1981

16. Mariotti S, Caturegli P, Piccolo P, Barbesino G and Pinchera A Antithyroid peroxidase autoantibodies in thyroid diseases. J Clin Endocrinol Metab 71: 661-669, 1990.

17. Feldt-Rasmussen U,Høier-Madsen M, Bech K, et al: Anti-thyroid peroxidase antibodies in thyroid disorders and non-thyroid autoimmune diseases. Autoimmunity 9: 245-254, 1991.

18. Gogas J, Kouskos E, Tseleni-Balafouta S, Markopoulos C Revenas K, Gogas G and Kostakis A: Autoimmune thyroid disease in women with breast carcinoma. Eur J Surg Oncol 27: 626-630, 2001.

19. Myhill J, Reeve TS and Hales IB: Thyroid function in breast cancer. Acta Endocrinol (Copenh) 51: 290-300, 1996.

20. Giani C, Fierabracci P, Bonnaci R, et al: Relationship between breast cancer and thyroid disease: relevance of autoimmune thyroid disorders in breast malignancy. J Clin Endocrinol Metab 81: 990-994, 1996.

21. Smyth PP: Autoimmune thyroid disease and breast cancer: a chance association? J Endocrinol Invest 23: 42-43, 2000.

22. Sarlis NJ, Gourgiotis L, Pucino F and Tolis GJ: Lack of association between Hashimoto thyroiditis and breast cancer: a quantitative research synthesis. Hormones (Athens) 1: 35-41, 2002.

23. Simon MS, Tang MT, Bernstein L, et al: Do thyroid disorders increase the risk of breast cancer? Cancer Epidemiol Biomarkers Prev 11: 1574-1578, 2002.
24. Cristofanilli M, Yamamura Y, Kau SW, et al: Thyroid hormone and breast carcinoma. Primary hypothyroidism is associated with a reduced incidence of primary breast carcinoma. Cancer 103: 1122-1128, 2005

25. Farahati J, Roggenbuck D, Gilman E, Schütte M, Jagminaite E, Seyed Zakavi R, Löning $\mathrm{T}$ and Heissen E: Anti-thyroid peroxidase antibodies are associated with the absence of distant metastases in patients with newly diagnosed breast cancer. Clin Chem Lab Med 50: 709-714, 2012.

26. Prinzi N, Baldini E, Sorrenti S, et al: Prevalence of breast cancer in thyroid diseases: results of a cross-sectional study of 3,921 patients. Breast Cancer Res Treat 144: 683-688, 2014.

27. Rodien PM, Madec AM, Ruf J, et al: Antibody-dependent cell-mediated cytotoxicity in autoimmune thyroid disease: relationship to antithyroperoxidase antibodies. J Clin Endocrinol Metab 81: 2595-2600, 1996.

28. Bhattacharya A and Vonderhaar BK: Specific binding proteins for 3,5,30-triiodothyronine in mouse mammary epithelium. J Cell Biol 75: 47a, 1977.

29. Selliti DF, Tseng YC and Latham KR: Nuclear thyroid hormone receptor in $\mathrm{C} 3 \mathrm{H} / \mathrm{HeN}$ mouse mammary glands and spontaneous tumors. Cancer Res 43: 1030-1038, 1983.

30. Smallridge RC and Latham KR: Nuclear thyroid hormone receptor in human breast tumors. Clin Res 28: 421, 1980.

31. Cerbon MA, Pichon MF and Milgrom E: Thyroid hormone receptors in human breast cancer. Cancer Res 41: 4167-4173, 1981.

32. Spitzweg C, Joba W, Eisenmenger W and Heufelder AE: Analysis of human sodium iodide symporter gene expression in extrathyroidal tissues and cloning of its complementary deoxyribonucleic acids from salivary gland, mammary gland, and gastric mucosa. J Clin Endocrinol Metab 83: 1746-1751, 1998.

33. Kilbane MT, Ajjan RA, Weetman AP, Dwyer R, McDermott EW, O'Higgins NJ and Smyth PP: Tissue iodine content and serum-mediated ${ }^{125} \mathrm{I}$ uptake-blocking activity in breast cancer. J Clin Endocrinol Metab 85: 1245-1250, 2000.

34. Stadel BV: Dietary iodine and risk of breast, endometrial, and ovarian cancer. Lancet 1: 890-891, 1976. 